(C) Inra/Elsevier, Paris

Original article

\title{
Analysis of the export of diffuse phosphorus from a small rural watershed
}

\author{
Lionel Jordan-Meille ${ }^{\mathrm{a}}$, Jean-Marcel Dorioz ${ }^{\mathrm{a}^{*}}$, Dean Wang ${ }^{\mathrm{b}}$ \\ ${ }^{a}$ Inra, 75, avenue de Corzent, BP 511, 74203 Thonon-les-Bains, France \\ ${ }^{\mathrm{b}}$ School of Natural Resources, University of Vermont, Burlington, VT 05405, USA
}

Received 30 September 1997; accepted 16 January 1998

\begin{abstract}
Phosphorus is an important pollutant leading to lake eutrophication. Diffuse pollution accounts for a substancial share of the total phosphorus load. To improve our knowledge of this pollution, we conducted a watershed study in a small, rural, 302-ha watershed (Lake Léman area). To study the spatial distribution and temporal dynamics of phosphorus in the watershed and the corresponding variation in phosphorus speciation, 40 stormflow events over a 4year period were analysed. We began by defining the 'state' of the watershed using a) periodic field surveys of signs of erosion, $b$ ) the length of the flowing ditches and streams (active hydrological network) and the waterpathways on the fields, c) the overall water budget, and d) grab samples of stream water from a network of subwatersheds. Four states that reflected contrasting watershed conditions were identified. Analysis of the data on phosphorus flux at the outlet of the watershed, in conjunction with the observations on the state of the watershed, allowed us to develop a conceptual model of phosphorus export from the watershed and several hypotheses about phosphorus transfer. (@ Inra/Elsevier, Paris.)
\end{abstract}

\section{phosphorus / diffuse pollution / state of the watershed / high-flow typology / seasonal cycles}

Résumé - Analyse des exportations de phosphore d'origine diffuse d'un bassin versant rural. On cherche, à travers l'étude d'un bassin versant rural, à identifier les mécanismes de la pollution diffuse phosphorée, ses modalités d'émission et de transport et ses impacts potentiels sur les milieux récepteurs. Les exportations de phosphore ont été étudiées pendant 4 ans sur le Mercube, bassin versant rural de 302 ha sans pollution ponctuelle, situé sur la rive française du Léman. Le principe de l'étude consiste à comparer des «états de bassin » avec des flux et des spéciations mesurés à son exutoire. La définition de l'état de bassin repose sur des campagnes d'observation et de mesures des écoulements présents sur le bassin versant. Quatre états reflétant des situations hydriques contrastées ont été définis. Ils se distinguent par la diversité spatiale des différents stocks de phosphore mis en jeu. Leur succession saisonnière décrit un cycle étroitement lié aux cycles culturaux et météorologiques. Afin de comprendre l'influence de ces états sur les quantités de phosphore émises vers le lac et sur sa spéciation, une quarantaine de crues ont été échantillonnées à l'exutoire du bassin.

Communicated by Marco Trevisan (Piacenza)

* Correspondence and reprints

E-mail: dorioz@thonon.inra.fr 
Cette analyse des transferts diffus de phosphore nous amène à proposer un modèle typologique des exportations de phosphore. Elle aboutit aussi à renouveler les conceptions concernant les processus de transfert des formes solubles et particulaires de phosphore. (@ Inra/Elsevier, Paris.)

phosphore / pollution diffuse / état de bassin / typologie des crues / cycles saisonniers

\section{INTRODUCTION}

Lake eutrophication is prevented by controlling phosphorus transfer from the watershed [39]. Despite the many factors influencing phosphorus effects in lakes, estimation of impacts is often limited to determining phosphorus speciation and estimating its potential bioavailability [85].

In the past, research was mainly directed towards point sources of pollution. As techniques now exist to control this type of pollution, efforts have turned towards diffuse sources, which account for a substantial share of phosphorus pollution $[14,49]$ and often appear to prevent lake restoration $[69,79,83]$. Diffuse sources of phosphorus contibute only during rainy periods or at snowmelt, from urban, agricultural or natural soils $[30,56]$.

Phosphorus emission studied during simulated rainfall [70] or natural rainfall, appeared to be strongly linked to the occurrence of surface runoff and erosion $[1,29,39]$ and mainly takes place in particulate form [44].

Runoff and erosion are partly dependent on both fixed (geo-morphology, soil quality) and seasonal (meteorology, soil use) factors [50]. In western Europe, the amount of rain cumulated between the last tillage and the rain event under consideration is mainly responsible for the extent of structural degradation of the soil surface and its ability to facilitate surface runoff [7]. In the same field, different forms of runoff can occur depending on the meteorological conditions and the structural state of the soil surface $[17,50]$ and leading to hortonian or saturated surface runoff. In addition, lateral subsuperficial transfer can bring water to the lower parts of the watershed [52]. Finally, we can expect the phosphorus emission to be as variable as the different forms of runoff.

Studies on diffuse pollution not only include emission but also transport, storage and transformation processes. Various studies show that phosphorus transport is a non-continuous phenomenon (described as a spiraling process by Newbold et al. [55]) where phosphorus is taken up and then released in a cycle as it moves downstream [11, 41] resulting in a delay in export and speciation changes $[21,22,66,76]$.

At the scale of the watershed, the phosphorus transfer is due to the combination of the emission and transport processes. The result is that the phosphorus export varies widely over individual storm events or over typical annual cycles [23]. Because of this complexity, modeling of phosphorus transfer is often inadequate because it does not take all the components of transfer into consideration.

The most commonly used modeling approach employed to predict phosphorus export from a watershed is an empirical one. It uses the weighted sum of the phosphorus areal load (in $\mathrm{kg} \cdot \mathrm{ha}^{-1}$.year ${ }^{-1}$ ) of every land use in the watershed [63]. This approach is unsatisfactory as it does not take into account the hydrological processes linked to transport and masks the temporal variability of the emissions and effects linked to spatial organization [84]. Mechanistic models such as CREAMS or WEPP [29, 45] have a clear theoretical approach, but are not adapted to working on the watershed scale and usually require data that are not available, which limits their applicability [42]. Moreover, the splash erosion component of the universal equation of soil loss [86] used in the algorithms to calculate erosion, is not representative of the phenomena observed in western Europe [7]. 
This paper shows how knowledge of phosphorus distribution and dynamics at the watershed-scale can help us to understand the phosphorus export regimes and lead to better prediction and control of phosphorus loading to surface waters. Our research has been centered on a comprehensive study at the watershed-scale and considered the watershed as an interconnected system of hydrologically active groups of fields, linked to an outlet through a hydrologic network where phosphorus can be retained and transformed. Under certain conditions, short-term events such as precipitation or frozen soils, might lead to a) an extension of the active zones, b) a modification in the mode of runoff generation and c) an increase in the length of the hydrologic network. Some medium-term perturbations consists of plant growth and agricultural activity. In the long-term, the watershed is affected by land management policy [12].

The study site, a 302-ha rural watershed, is part of a research program to study Lake Léman (a mesotrophic lake measuring $90 \mathrm{~km}^{3}$ ) and its watershed $[4,6,10,60]$.

The approach is based on the comparison between a) chemical and flow dynamics of the stream and b) 'the state of the watershed', in order to develop a typology relating phosphorus export to the watershed and its surface drainage. This typology provides an empirical explanation for patterns of phosphorus export to surface waters, and fosters the development of testable hypotheses on watershed function with particular emphasis on phosphorus emission, transport, storage and transformation. The 'state of the watershed' determines its ability to generate runoff for any particular rain event and to transfer stocks of phosphorus to the outlet. This state is based on a) observations on where and when runoff occurs, b) the extent and pattern of connections in the hydrologic network, and c) calculated water balances for soils and the whole watershed. Hydrochemical data to compare with watershed state consisted of event-based measures of phosphorus concentration for a variety of phosphorus species and flow measurements.

\section{DESCRIPTION OF THE STUDY AREA}

The Mercube watershed (figure 1) is situated on the southern side of Lake Léman (France), in a rural area containing scattered housing. The Mercube drains the 302-ha watershed which is characterized by gentle relief (slopes of 0-8\%) as shown on the geo-morphological map (figure 2).

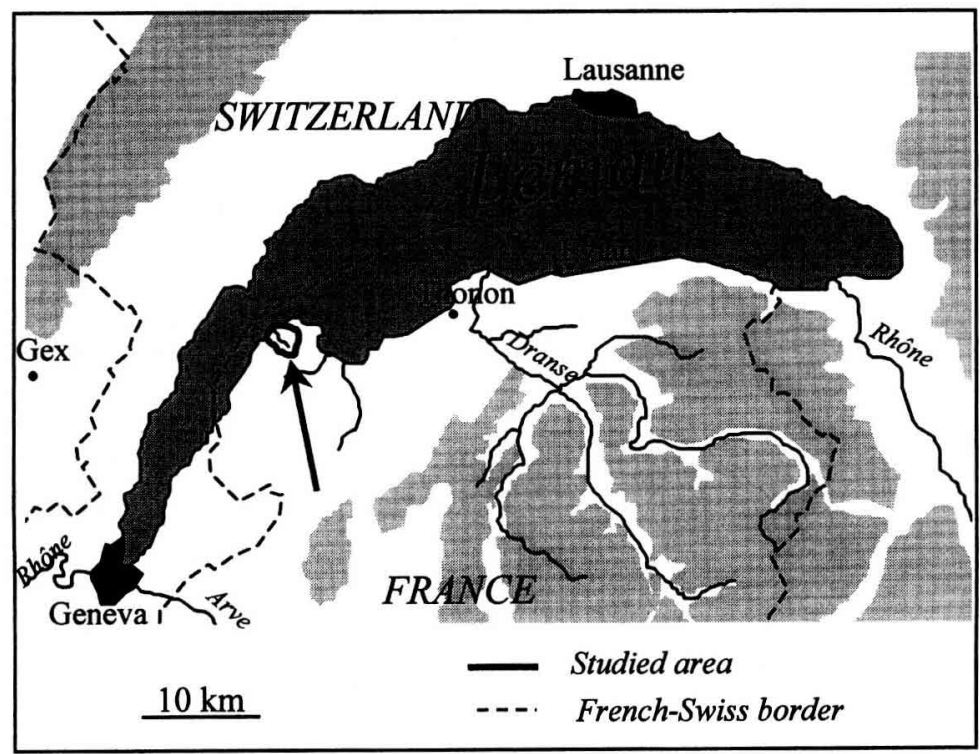

Figure 1. Localization of the study zone. 

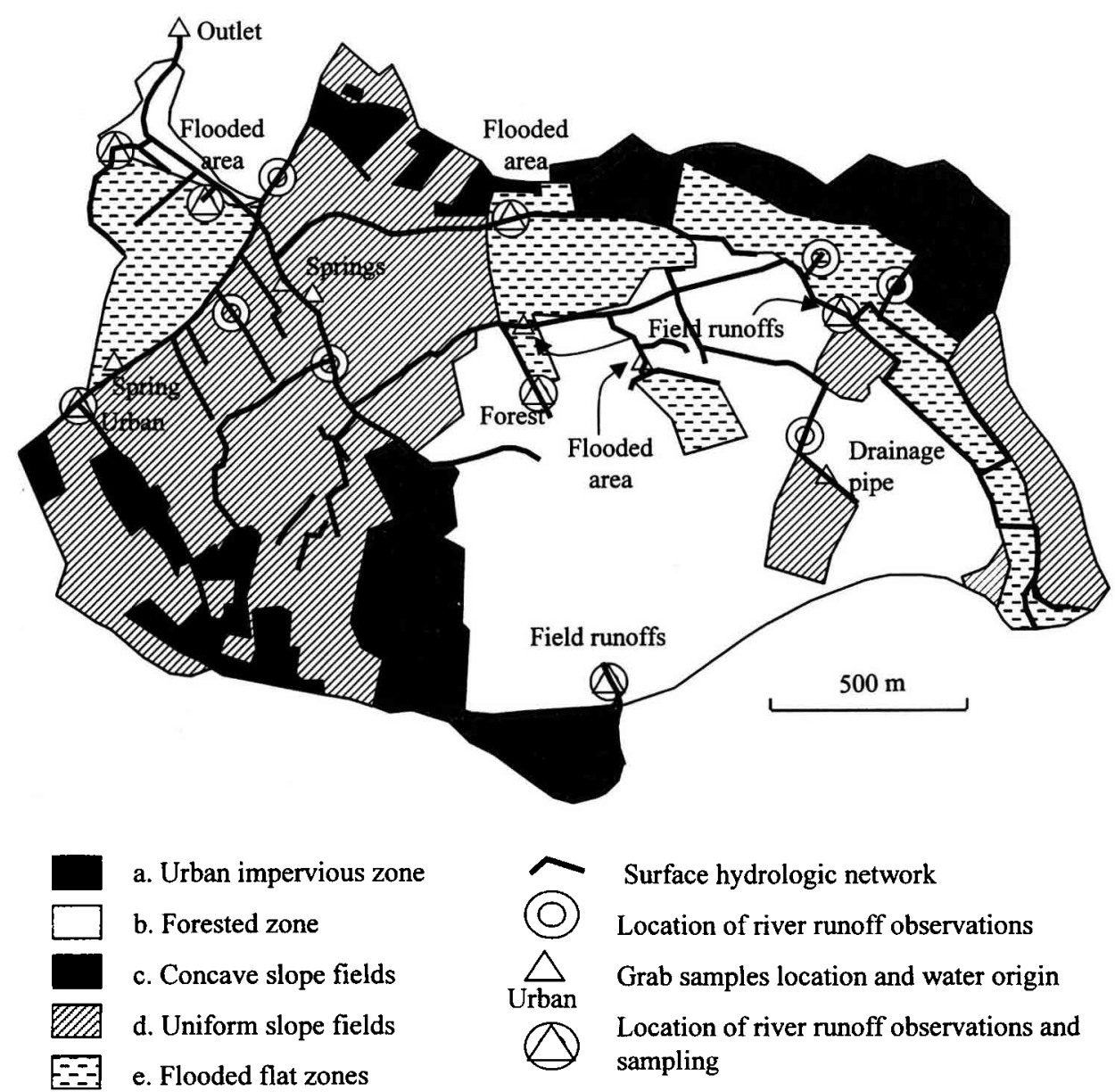

a. Urban impervious zone

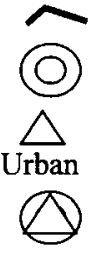

Surface hydrologic network

b. Forested zone

Location of river runoff observations

c. Concave slope fields

d. Uniform slope fields

e. Flooded flat zones

Grab samples location and water origin

Location of river runoff observations and

sampling

Figure 2. Soil occupation, geomorphological areas and localization of runoff test and measurement points of the watershed.

The study area is characterized by three topographic conditions: 1) concave sloped fields subject to water logging in winter, 2) uniformly sloped fields, and 3) flat zones drained by deep ditches $(1.5 \mathrm{~m})$. The soils are mainly carbonated brown soils, whose thickness $(50-150 \mathrm{~cm})$ depends on their topographic position. Surveys showed that agriculture could be considered as quite intensive, with a mean load of fertilizer applied reaching 16 $\mathrm{kgP} \mathrm{ha}^{-1}$.year ${ }^{-1}$. Total phosphorus content varies from $400 \mu \mathrm{gP}^{-1} \mathrm{~g}^{-1}$ soil in grassland to 1200 in cultivated fields. Concerning the available phosphorus content [57], the range is from $10 \mu \mathrm{gP}_{\text {Olsen }} \cdot \mathrm{g}^{-1}$ in grassland to $60 \mu \mathrm{gP}_{\text {Olsen }} \cdot \mathrm{g}^{-1}$ in cultivated fields, which is higher than the optimum yield response (28 $\mu \mathrm{gP}_{\text {Olsen }} \cdot \mathrm{g}^{-1}$ for Morel et al. [54]). Heavy soils prone to hydromorphy and unsuitable for agriculture are covered by forest (123 ha), and often have a perched water table in winter. The rest of the area is divided among wheat and corn fields (120 ha), grassland (50 ha) and urban impervious surfaces (roofs, roads and footpaths, $9 \mathrm{ha}$ ). There are a total of 170 agricultural fields averaging $100 \mathrm{~m}$ in length. Only one of these fields is artificially drained. Because of the gentle slopes and short length of fields, runoff is generally not able to concentrate and only rarely leads to shallow gullies in the fields [81]. 
The subsoil of the watershed consists of an impervious calcareous till, which favors surface and subsurface runoff and reduces infiltration [36]. The hydrologic network (streams and ditches) presents a drainage density of $35 \mathrm{~m} \cdot \mathrm{ha}^{-1}$. In the lower forested part of the watershed, the river banks are subject to erosion when rainfall is heavy. Several isolated sandy layers of subsoil create perennial springs, which are the dominant source of stream water during low flow conditions. This water has a high $\mathrm{CaCO}_{3}$ content. All the housing in the watershed is linked up to a sewer system, so there are no point source contributions to the stream.

\section{METHODS}

\subsection{Hydrochemical data acquisition}

An automatic sampler was used at the outlet of the watershed. A sampling interval from 10 to 15 min was employed, depending on the discharge. Flow rate was measured with a water level gauge on a water flume. Precipitation data were obtained from a meteorological station established at the study site. During the study period (January 1993-January 1997) two sampling strategies were followed (table I). In the first phase (January 94-August 95), sampling of the stream outlet only allowed annual phosphorus fluxes to be calculated. In the second phase of sampling, analyses were carried out more frequently (one bottle per hour during high flow), allowing high-flow event fluxes to be more accurately calculated. This sampling frequency was also applied to two summer high flows during phase one sampling (14 July 94 and 10 August 94). During this second phase of the study, the state of the watershed was recorded, enabling the relationship between hydrochemistry and the state of the watershed to be described.

From January 93 to August 95, repeated grab sampling of the hydrologic network was carried out for 15 points scattered over the whole watershed. The sampling points were selected so that a variety of soil and emission conditions were represented (figure 2). Phosphorus concentrations were measured in runoff from farmland (surface water and artificial drainage outlet channels), urban areas and the forested zone. Phosphorus content of rainwater was also regularly monitored.

Samples were maintained at $4{ }^{\circ} \mathrm{C}$ and analysed within 1 week. This storage protocol was found to have a negligible impact on the parameters analysed [62]. The following parameters were measured:

- total suspended solids (TSS) were measured by filtration of water samples of between 100 and $600 \mathrm{~mL}$ through pre-weighed $\mathrm{GF} / \mathrm{F}$ Whatman filters (pore diameter of $0.7 \mu \mathrm{m}$, CIPEL [15]);

- total phosphorus (TP) in unfiltered water, total phosphorus in filtered water $(0.7 \mathrm{~mm})$ (SP for soluble phosphorus) and molybdate-reactive phosphorus considered as orthophosphates (SRP for soluble reactive phosphorus); phosphorus was analysed according to standard methods (E.N. 1189 [27]). Total and dissolved phosphorus were converted to

Table I. Sampling strategies and monitoring program during the study period.

\section{During low flow conditions During high flows Possible calculations Other monitoring and observations}

\section{Period 1 weekly mean samples carried out by a flow}

Jan 93 to proportional mix of 21 bottles representing $8 \mathrm{~h}$

- annual load

Aug 95

(32 samples at 15 -min intervals)

Period 232 samples at $15-\mathrm{min}$

Aug 95 to intervals, i.e. 1 bottle

Jan 97

every $8 \mathrm{~h}$

$$
\begin{array}{lll}
6 \text { samples at } 10 \text {-min } & \text { - annual load } & \text { - \% of crusted soil. } \\
\text { intervals, i.e. } 1 \text { bottle } & \text { - export P during } & \text { - connections map. } \\
\text { every hour } & \text { high-flow event } & \text { - runoffs map }
\end{array}
$$
of 15 points in the watershed 
orthophosphate by acid persulphate digestion in an autoclave; particulate phosphorus (PP) was obtained from the difference between TP and SP. Tss phosphorus content is expressed in $\mu \mathrm{gP} . \mathrm{g}^{-1}$ sediment.

- $\mathrm{Cl}$ and $\mathrm{NO}_{3}$ were measured using ion chromatography (E.N. 10304 [26]).

\subsection{Description of the watershed during storm-flow events}

During high-flow events, systematic observations of fields within the watershed were made. These observations focused on the hydrologically active zones and the manner in which runoff was generated and transported off the fields.

The extent and condition of the hydrologic network and the corresponding hydrologically active zones were mapped during each measured highflow event (August 95 to January 97). This map was based on the observation of the presence of water along 13 reference sample points situated within the hydrologic network (figure 2). The length of the actively flowing network is directly linked to the water conditions at the initiation of high-flow event, the level of the water table, and the potential effect of rain on the resulting flow. The rain event was characterized by its volume and intensity at 15-min sampling intervals.

Runoff conditions were observed during rain events on a representative sample of cultivated fields by distinguishing when runoff occurred as sheet flow, occurred in ditches or tire tracks, or extended to the bottom of fields on slopes [7, 81]. Additional information was obtained by observing the state of the soil surface and signs of erosion [7].

\subsection{Calculations}

\subsubsection{High-flow event duration}

The high-flow period is defined as beginning with an increase in flow and ending when the con- centration of orthophosphate (SRP) returned to its original level. The return to the base flow rate could not be chosen as a criterion as this only occurred during small high-flow events in summer. Nevertheless, on the basis of the SRP criterion, the end of the high-flow event corresponded to a flow rate that closely resembled the initial base flow (within $10 \%$ of the base flow). Multipeak events were treated as a single high-flow event.

\subsubsection{Exports and mean concentrations}

For every high-flow event, exported load was calculated by summing up, during the predefined period, the products of instantaneous concentrations, flow and time interval represented by the sample collected [80]. The mean concentration was obtained by dividing load by the corresponding volume of water.

\subsubsection{Runoff/precipitation ratio}

The runoff/precipitation ratio was defined as the ratio of the high-flow volume, expressed in $\mathrm{mm}$ equivalents for the watershed area, by the amount of precipitation falling during the high flow. The value of this ratio is a function of the state of the active surfaces and their hydrologic connection to the outlet. It is used as one component determining the state of the watershed.

\subsubsection{Initial amount of soil water}

The initial amount of soil water is a relative value that results from the hydrological balance of the watershed, established from the beginning of the study period (1 January 1993) to the day before the high-flow event. Precipitations and runoff at the outlet are directly measured, whereas evapotranspiration (EVT) is calculated from Penman's formula [9]. As the hydrological budget is fairly constant from one year to the next (inputs = outputs), comparisons of this calculated reservoir of soil water from one year to the next are justified. 


\section{RESULTS}

\subsection{Variability of phosphorus fluxes at the outlet}

The annual TP fluxes at the outlet vary by a factor of 3 (table II) over 4 years although annual precipitation and agricultural practices, and use of the fields remained nearly constant. The variability in the annual flux of PP is of the same order of magnitude as that of TSS (45\%) and more than that of SP (5\%), nitrates $(9 \%)$ and chlorides $(6 \%)$. The TP losses correspond to phosphorus agricultural areal load varying from 0.3 to $1.4 \mathrm{~kg}$. ha ${ }^{-1}$.year ${ }^{-1}$. This range of agricultural loads includes urban impervious zones (approximately 0.4 kg.ha ${ }^{-1}$.year ${ }^{-1}$, CIPEL [15]) and exports from the forest and grassland soil surface $\left(0.2 \mathrm{~kg} \cdot \mathrm{ha}^{-1}\right.$.year ${ }^{-1}$ [62]). These losses were negligible in relation to the estimated stock of phosphorus in the soil (between 500 and $2500 \mathrm{~kg} \cdot \mathrm{ha}^{-1} \cdot \mathrm{year}^{-1}$ for the 0-30 $\mathrm{cm}$ layer) and very low in relation to agricultural input (from 15 to $20 \mathrm{~kg} \cdot \mathrm{ha}^{-1} \cdot \mathrm{year}^{-1}$ ) and export from crops (from $10 \mathrm{~kg} \cdot \mathrm{ha}^{-1} \cdot \mathrm{year}^{-1}$ ) according to regional data.
On average, the SP phosphorus fraction only represented $20 \%$ of the total phosphorus export of the outlet, orthophosphates (SRP) represented 70 $\%$ of soluble phosphorus. These ratios of phosporus species changed little from one year to the next. The annual mean concentration of all forms of phosphorus tended to increase with the volume produced; the opposite tendency was true for nitrates and chlorides.

Under low flow conditions, TP concentrations were very low and stable $\left(<0.020 \mathrm{mg} . \mathrm{L}^{-1}\right.$, of which $50 \%$ was SP). There was no seasonal influence. During high flows, the TP concentrations can vary by a factor of 100 . The peak in concentration usually occurred at the start of the high-flow event. The maximum amount measured was $1 \mathrm{mg} . \mathrm{L}^{-1} \mathrm{TP}$ consisting of $20 \%$ SP.

Each high-flow event was taken as an observational unit with total $\mathrm{P}$ export compared on that basis. P export by high-flow event, shown in table III, varied from 0.03 to $38 \mathrm{~kg}$ for durations of $8 \mathrm{~h}$ to 8 weeks, respectively. These variations could be attributed a priori either to different 1) volumes or 2) concentrations. Our question was then to establish the relative importance of each and to determine how each related to the state of the watershed.

Table II. Annual balances of exported matter at the Mercube outlet.

\begin{tabular}{|c|c|c|c|c|c|c|c|c|}
\hline & $\mathrm{TP}$ & SP & SRP & $\mathrm{NO}_{3}$ & $\mathrm{Cl}$ & TSS & Rain (mm) & Vol. water $\left(\mathrm{m}^{3}\right)$ \\
\hline $\begin{array}{l}1993 \mathrm{~kg} \\
\left(\mathrm{mg} \cdot \mathrm{L}^{-1}\right)\end{array}$ & $\begin{array}{c}146 \\
0.155\end{array}$ & $\begin{array}{c}28 \\
0.03\end{array}$ & $\begin{array}{c}20 \\
0.021\end{array}$ & $\begin{array}{l}3506 \\
3.73\end{array}$ & $\begin{array}{c}12334 \\
13.1\end{array}$ & $\begin{array}{c}251000 \\
267\end{array}$ & 1100 & $0.93 * 10^{6}$ \\
\hline $\begin{array}{l}1994 \mathrm{~kg} \\
\left(\mathrm{mg} \cdot \mathrm{L}^{-1}\right)\end{array}$ & $\begin{array}{c}88 \\
0.12\end{array}$ & $\begin{array}{c}20 \\
0.025\end{array}$ & $\begin{array}{c}13 \\
0.017\end{array}$ & $\begin{array}{c}2784 \\
3.54\end{array}$ & $\begin{array}{c}10851 \\
13.8\end{array}$ & $\begin{array}{c}86000 \\
109\end{array}$ & 1071 & $0.79 * 10^{6}$ \\
\hline $\begin{array}{l}1995 \mathrm{~kg} \\
\left(\mathrm{mg} \cdot \mathrm{L}^{-1}\right)\end{array}$ & $\begin{array}{c}214 \\
0.186\end{array}$ & $\begin{array}{c}40 \\
0.035\end{array}$ & $\begin{array}{c}26 \\
0.023\end{array}$ & $\begin{array}{c}2914 \\
2.53\end{array}$ & $\begin{array}{c}12188 \\
10.6\end{array}$ & $\begin{array}{c}204000 \\
178\end{array}$ & 1140 & $1.15^{*} 10^{6}$ \\
\hline $\begin{array}{l}1996 \mathrm{~kg} \\
\left(\mathrm{mg} \cdot \mathrm{L}^{-1}\right)\end{array}$ & $\begin{array}{c}130 \\
0.156\end{array}$ & $\begin{array}{c}32 \\
0.04\end{array}$ & $\begin{array}{c}21 \\
0.025\end{array}$ & $\begin{array}{c}2938 \\
3.5\end{array}$ & $\begin{array}{c}10988 \\
13.1\end{array}$ & $\begin{array}{c}119000 \\
142\end{array}$ & 1020 & $0.87 * 10^{6}$ \\
\hline $\begin{array}{l}\text { Mean kg } \\
\left(\mathrm{mg} \cdot \mathrm{L}^{-1}\right)\end{array}$ & $\begin{array}{c}145 \\
0.154\end{array}$ & $\begin{array}{c}30 \\
0.032\end{array}$ & $\begin{array}{c}20 \\
0.022\end{array}$ & $\begin{array}{c}3036 \\
3.32\end{array}$ & $\begin{array}{c}11590 \\
12.7\end{array}$ & $\begin{array}{c}165000 \\
174\end{array}$ & 1083 & $0.93 * 10^{6}$ \\
\hline
\end{tabular}


Table III. Descriptive parameters of the state of the watershed (A), state typology (B) and hydrochemical response at the outlet $(\mathrm{C})$. The symbol * refers to maximum water reserve values in the watershed and rain. The dates in bold correspond to signs of erosion and in general to when two maximum values (A) coincided. Unavailable data are indicated by?

\begin{tabular}{|c|c|c|c|c|c|c|}
\hline \multirow[b]{2}{*}{ Date of high flow } & \multicolumn{3}{|c|}{$\begin{array}{l}\text { A. Factors defining the } \\
\text { state of the watershed }\end{array}$} & \multirow{2}{*}{$\begin{array}{l}\text { B: Typology } \\
\text { of the states } \\
\text { Type of state }\end{array}$} & \multicolumn{2}{|c|}{$\begin{array}{l}\text { C. Hydrochemical response of } \\
\text { the watershed at the outlet }\end{array}$} \\
\hline & $\begin{array}{l}\text { Stock } \\
(\mathrm{mm})\end{array}$ & $\begin{array}{l}\text { Rain } \\
(\mathrm{mm})\end{array}$ & $\begin{array}{l}\text { Active length } \\
\text { (m) }\end{array}$ & & $\begin{array}{l}\text { Exported TP } \\
(\mathrm{kg})\end{array}$ & $\begin{array}{l}\text { Runoff Coef. } \\
(\%)\end{array}$ \\
\hline 14 Jul 94 & -105 & 27 & 2662 & 1 & 0.17 & 0.82 \\
\hline 10 Aug 94 & -146 & 13 & 2662 & 1 & 0.03 & 0.22 \\
\hline 11 Jul 95 & $8.5^{*}$ & $?$ & 2662 & 1 & 0.09 & $?$ \\
\hline 24 Aug 95 & -161 & 29 & 2662 & 1 & 0.148 & 0.36 \\
\hline 7 Sept 95 & -148 & $60 *$ & 3074 & 2 & 0.52 & 0.50 \\
\hline 12 Sept 95 & -96 & $76^{*}$ & 5923 & 2 & 3.3 & 4.7 \\
\hline 24 Sept 95 & -34 & 32 & 6433 & 2 & 1.33 & 4.2 \\
\hline 5 Oct 95 & -25 & $?$ & 2662 & 1 & 0.104 & $?$ \\
\hline 29 Oct.95 & -38 & 25 & 5143 & 2 & 0.32 & 1.1 \\
\hline $22 \operatorname{Dec} 95$ & $10^{*}$ & 32 & 6966 & 2 & 1.96 & 9.3 \\
\hline $25 \operatorname{Dec} 95$ & $39 *$ & 31 & $?$ & $?$ & 13.3 & 32.5 \\
\hline 7 Jan 96 & $48^{*}$ & 20 & 10411 & 3 & 5.45 & 35.3 \\
\hline 12 Feb 96 & $43^{*}$ & 24 & 10411 & 3 & 5.37 & 39.8 \\
\hline 1 Apr 96 & $16^{*}$ & 13 & 4871 & 2 ' & 0.32 & 5.3 \\
\hline 8 May 96 & -12 & 20 & 4601 & 2 ' & 0.78 & 7.4 \\
\hline 7 June 96 & -7 & 26 & 10411 & 4 & $?$ & 26.7 \\
\hline 21 June 96 & -22 & 20 & 2662 & 1 & 0.08 & 0.3 \\
\hline 5 July 96 & -31 & $60^{*}$ & 6765 & 2 & 1.7 & 2.2 \\
\hline 7 July 96 & $23^{*}$ & $64 *$ & 10411 & 4 & 27.2 & 37.7 \\
\hline 5 Nov 96 & -87 & 15 & 2662 & 1 & 0.04 & 0.6 \\
\hline 12 Nov 96 & -66 & 37 & 7828 & 2 & 5.85 & 14.9 \\
\hline 27 Nov 96 & $22^{*}$ & 16 & 10411 & 3 & 2.69 & 26.5 \\
\hline $13 \mathrm{Dec} 96$ & $31 *$ & 37 & 10411 & 3 & 7.17 & 40.7 \\
\hline $19 \operatorname{Dec} 96$ & $49^{*}$ & $45^{*}$ & 10411 & 4 & 25.2 & 42.9 \\
\hline 23 Dec 96 & $68^{*}$ & 21 & 10411 & 3 & 5.79 & 50.3 \\
\hline 19 Jan 97 & $52^{*}$ & $53^{*}$ & 10411 & 4 & 38.66 & 72.3 \\
\hline
\end{tabular}

\subsection{Evolutionary cycle of the watershed states}

Data on the watershed during high-flow events are presented chronologically in table III. These data demonstrate an annual cycle with different periods in which certain parameters are stable (e.g. in summer, network length is at a steady minimum and in winter it is at its maximum). In contrast, at certain times of the year, sudden changes (e.g. following intense events when erosion appears) or progressive change (e.g. structural degradation of fields, reactivation of the entire hydrologic network) was observed. Given this pattern, four characteristic watershed states were distinguished (table III) mainly based on the length of the active (inundated and flowing) hydrologic network and the mode of runoff on the fields during the rain event.

\subsubsection{State 1}

This watershed state corresponded to high-flow events occurring in periods of drought (summer- 
time, negative initial reserve) and was generally followed by a return to a low-flow condition $\left(\mathrm{Q}=3 \mathrm{~L} \cdot \mathrm{s}^{-1}\right)$. During the high-flow events, only the reference sample point situated downstream of the urban impervious zone showed a flow $\left(Q_{\max }<40{\mathrm{~L} . \mathrm{s}^{-1}}^{-1}\right.$. The active hydrologic network therefore consisted of a drain connecting the urban zone ( 9 ha) to the permanently flowing hydrologic network. No runoff was observed coming from the portion of the hydrologic network draining agricultural fields. Moreover, the soil water reservoir remained near the minimum ( stock $_{\text {mean }}<-90 \mathrm{~mm}$ ). These observations and estimates strongly suggest that agricultural runoff is only a minor component of streamflow at this time. Under the conditions of state 1 , the soil surface was optimal for infiltration (maximal plant cover and less than $10 \%$ of crusted agricultural soil surface, including compacted tire tracks). Thus, even for relatively high rainfall amounts $(30 \mathrm{~mm})$ and intensities $\left(16 \mathrm{~mm} \cdot \mathrm{h}^{-1}\right)$ no runoff was produced from agricultural areas. Over the study period, high-flows corresponding to state 1 represented $14 \%$ of the time the watershed was subject to precipitation.

\subsubsection{State 2}

This state followed state 1 (figure 3) and generally occurred in autumn when the length of the active hydrologic network increased owing to the filling up of some of the deep ditches. This phenomenon can be linked to the increase in the reservoir of soil water owing to precipitation and a large decrease in EVT. Over the years studied, $60-80 \mathrm{~mm}$ of net precipitation was necessary to progress from state 1 to state 2. During these highflow events, 1) there were no signs of erosion, 2)

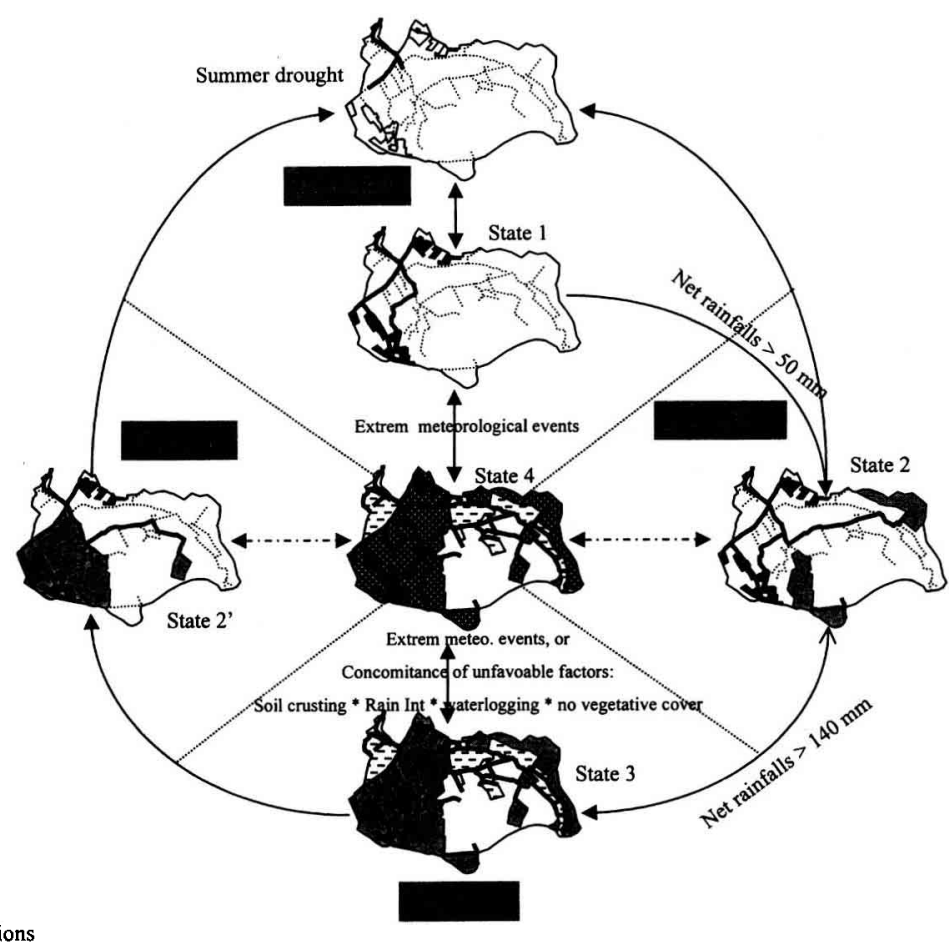

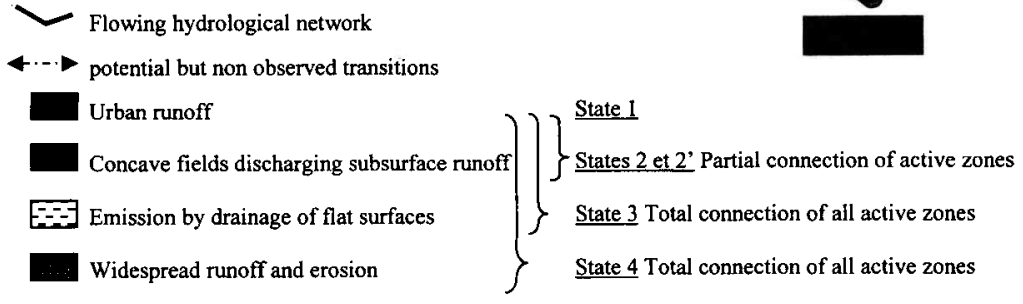

Figure 3. Evolution of the active zones and their main emission mode during a seasonal cycle. 
only a small percentage of the watershed soil surface was compacted owing to localized agricultural activity (silage corn, beetroot, 17 ha on average), and 3 ) diffuse runoff was only produced from fields at the bottom of slopes (concave fields in sectors $\mathrm{c}$ in figure 2). This suggests that water entering the hydrologic network is a result of either subsurface water exfiltration (lateral transfer above the plow pan; Cros-Cayot [17]), or runoff from saturated soil surfaces [52]. The length of the active hydrologic network in state 2 gradually evolved from its minimum length (state 1) to its maximum length (state 3 ). Type 2 high flows comprised about $24 \%$ of the total number of such events in a year.

\subsubsection{State 3}

Complete inundation of the hydrologic network (the active network is $100 \%$ of the total drainage system with all the reference sample points flowing, figure 2) resulted from a cumulative amount of net precipitation of $140-190 \mathrm{~mm}$ since the watershed was in state 2 . Under these conditions all remaining agricultural surfaces become hydrologically active. Those surfaces included uniform sloped fields, flat zones subject to flooding (sectors $\mathrm{e}$ in figure 2), and forested zones (sector b). No signs of erosion were detected; the crusted and compacted soil surface only affected $15 \%$ of cultivated land surface. Diffuse runoff from all the fields at the bottom of slopes, whether concave or uniform, was observed in addition to frequent soil crusting in flat zones (sector e). State 3 events were the most frequent of the four states representing 34 $\%$ of the annual total.

\subsubsection{State 4}

The length of the active hydrologic network was at a maximum in state 3 . Thus the basis for state 4 was the condition of the soil, its water content, and thus its potential for generating superficial and concentrated runoff. State 4 was characterized by compacted and crusted soil surfaces over large portions (from 15 to $50 \%$ ) of the watershed and numerous signs of erosion (sediments deposited at the bottom of fields, small gullies,...). Two meteorological conditions gave rise to this state.

1) Extreme meteorological conditions (exceptional amount and intensity of rain, rain on top of melting snow and frozen soils). Following a high intensity storm $\left(100 \mathrm{~mm} \cdot \mathrm{h}^{-1}\right.$ for $15 \mathrm{~min}$ on the 7 June 1996), all the corn fields in the watershed ( 40 ha) showed signs of erosion. Also, during a storm event on snow-covered soil (January 97), surface runoff was observed on all the fields (sectors $c$ and d); however, signs of erosion were found only in fields planted with winter cereals and soils that were cultivated and left bare after harvest.

2) This state was also reached when several unfavorable agro-meteorological factors coincided, e.g. high initial water reserve and amount of rainfall, a large percentage of bare soil, crusted soil surface. The proportion of agricultural crusted surface (high flows of 7 July 1996 and 19 December 1996) could reach $30 \%$ and the sum of the depth of the rain and relative water reserve exceeded $90 \mathrm{~mm}$ (table III).

Under extreme weather conditions, state 4 could be reached in any season and from any preceding state. However, this state was particularly frequent in winter owing to high soil moisture content. Comprising $12 \%$ of the total number of highflows, this was the least frequent state.

\subsubsection{State 2 ,}

This state of the watershed, corresponding to the winter/summer transition from state 3 to state 1 , was comparable to state 2 with the soil water reservoir, the active length of the hydrologic network, and the structure of the soil surface being very similar. A total of $16 \%$ of the high-flows occurred in this state.

\subsection{Water path and phosphorus stock interactions}

The phosphorus stocks most susceptible to export in runoff included 1) cultivated soils whose 
phosphorus content (TP) varied from 750 to $1500 \mu \mathrm{gP}^{-\mathrm{g}^{-1}}$ soil (determined from 30 samples, A-horizon), 2) the stream banks of the hydrologic network with a low phosphorus content from 250 to $500 \mu \mathrm{g} \cdot \mathrm{g}^{-1}$ (12 samples, usually soil horizons B and $C$ ), and 3) the sediment from the main hydrologic network with intermediate TP values of 750 to $850 \mu \mathrm{g} \cdot \mathrm{g}^{-1}$ (10 samples). Runoff at the outlet of the watershed represents a variable mix of these phosphorus stocks. Figure $4 a$ shows the TP content of waters sampled directly below different types of active source areas. Data obtained synoptically at the outlet are also presented for compari- son. TP concentrations were very variable. The perched water beneath forested zones that collects in winter and spring had the lowest TP concentrations (median $=0.01 \mathrm{mg} . \mathrm{L}^{-1}$ of which $70 \%$ is SP). These low values were consistent with other studies concluding that underground transfer of phosphorus is not an important phosphorus export process, especially in calcareous regions [51, 62]. In contrast, precipitation [14] contains more TP, originating from atmospheric dust. Urban runoff was very heavily loaded with TP $\left(0.5 \mathrm{mg} . \mathrm{L}^{-1}\right)$ with a large component of SP (65\%) originating from the flushing of impervious surfaces on which

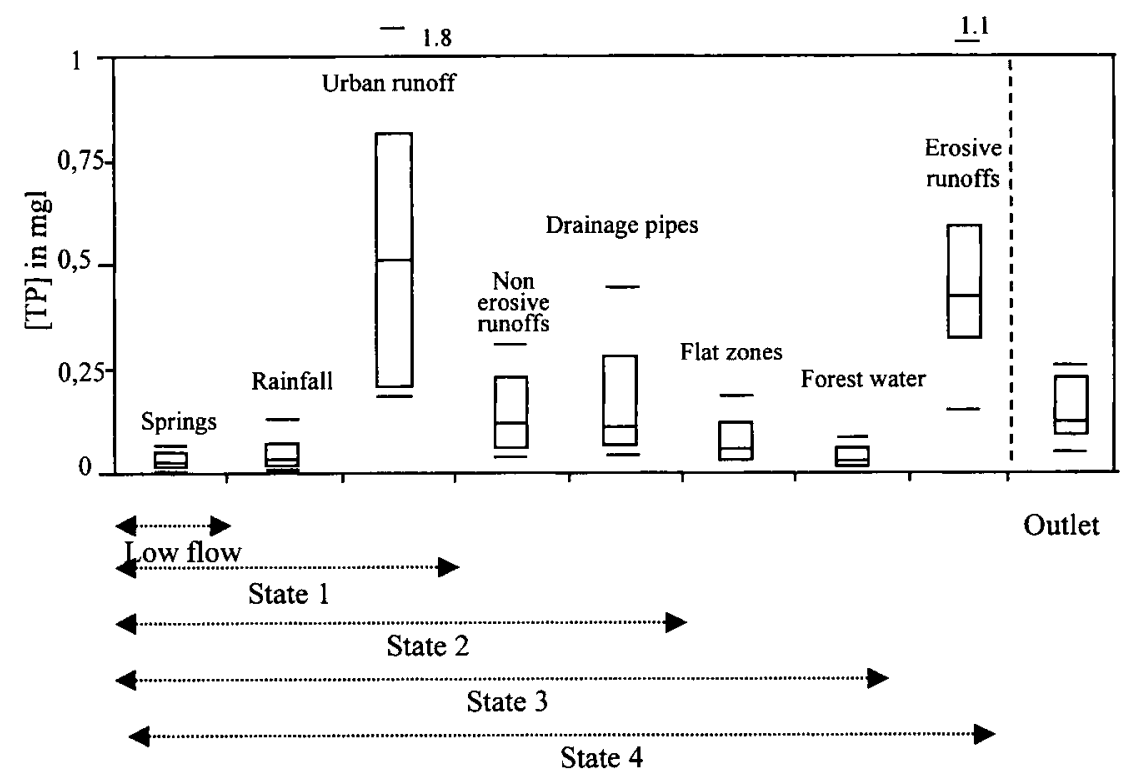

a)

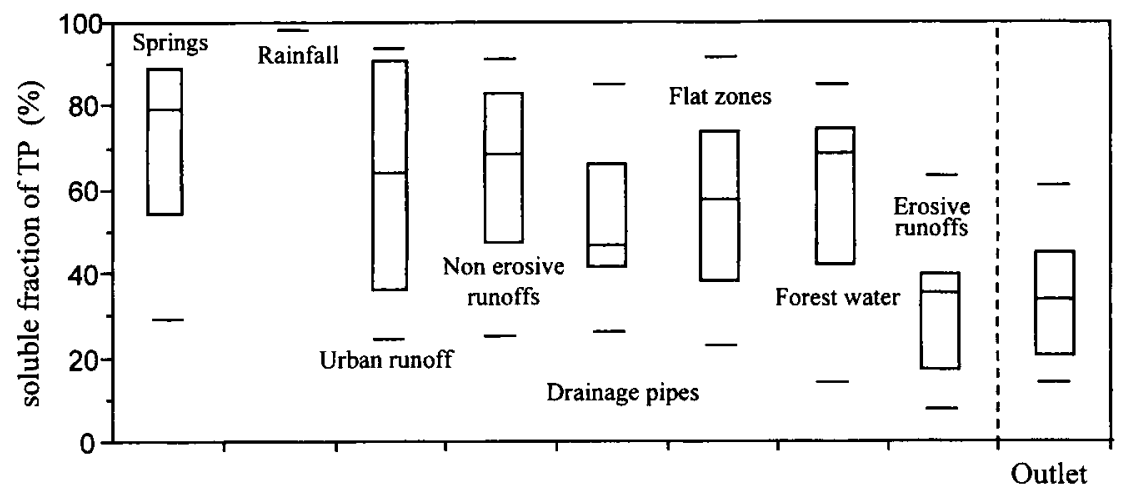

b)

Figure 4a. TP concentrations of the different types of water in the watershed. Results are presented in order of participation at the outlet, from low water condition to a state of total saturation. Comparison with outlet data, all data (types) combined. b. TP content in SP (percentage) of the different types of water. 
atmospheric dust settles in dry periods. A similar high concentration of TP was observed with erosive runoff, largely dominated by particulate phosphorus (PP) (figure 4b). For both urban and erosive runoff, the concentrations were highly variable with the highest observed phosphorus levels. In contrast, the proportion of SP was the lowest among the samples collected.

Water collect from agricultural zones under nonerosive conditions, e.g. from the bottom of slopes, showed lower mean concentrations of around $0.1 \mathrm{mg} . \mathrm{L}^{-1} \mathrm{TP}$ with SP as a dominant fraction (figure $4 a, b)$.

The contribution of each runoff type at the outlet varied according to the state of the watershed. In state 1 , the majority of the stream water originated from impervious zones. Urban phosphorus, phosphorus in rainfall, and phosphorus released by the resuspension of sediments dominate in this stream water. A mass balance calculated during the summer high flow of 14 July 1994 showed that sediments from within the hydrologic network released roughly $25 \mathrm{~g}$ TP from a 500-m stretch [41].

The extension of the hydrologic network in states 2 and 3 added new phosphorus sources associated with agricultural land (figure $4 a$ ). It is likely that the quantity of sediments remobilized increases proportionally with the increase in the length of the active hydrologic network and its flow rate. But it was not possible to measure any influence of previous events on the amounts of sediments. All the grab samples of water collected from the fields during states 2 and 3 had a high proportion of SP relative to TP. Water from the forested and flat zones, connected to the hydrologic network in states 2 and 3 , had a diluting effect.

In state 4 , other $\mathrm{P}$ sources that were highly concentrated in TP contribute to the total P load in stream water. Water associated with erosion of the fields was dominated by PP (figure $4 b$ ). In addition, the contribution of TP from stream banks, while not quantified by mapped changes in the stream profile, appeared to be an important component of TP in stream water during state 4 high flows. Signs of heavy erosion were noted in the downstream section of the stream.
The PP concentrations measured at the outlet during each of the four states, were comparable with those measured in the erosive runoff from fields during the state 4 . This situation could only be explained by taking into account the sediment stock in the hydrologic network sediment stock during states 1, 2 and 3 as a source of PP.

\subsection{State of the watershed and $P$ exports}

\subsubsection{State of the watershed and runoff ratios}

The runoff/precipitation ratio was clearly different from one watershed state to the others, as indicated below:

$$
\begin{array}{ll}
\text { state 1: } & 0.47 \% \pm 0.20 \\
\text { states 2 and 2': } & 6.15 \% \pm 4.10 \\
\text { states 3 and 4 : } & 38.67 \% \pm 6.34
\end{array}
$$

States 2 and 2', 3 and 4 have been grouped together because the active length of the hydrologic network and the extent of the connected fields were identical.

Thus, the state of the watersheds during a highflow event appears to be a sufficient variable to explain the volumes of outflow. Identification of this relationship then lead to the discovery of a more complex relationship between the volumes of water produced, the phosphorus loads exported, phosphorus speciation and the state of the watershed.

\subsubsection{State of the watershed and total phosphorus flux exported}

The relationship between the volume of water and the flux of TP exported in each high-flow event showed a highly significant positive linear correlation $\left(\mathrm{TP}(\mathrm{kg})=-0.73+0.00035^{*} \mathrm{~V}\left(\mathrm{~m}^{3}\right)\right.$, $\left.\mathrm{r}^{2}=0.87\right)$ for all the high-flow events studied (table III). This relationship is not surprising but shows that fluxes were thus essentially controlled by hydrological processes. The same relationship was observed for PP $\left(r^{2}=0.85\right)$ and SP $\left(r^{2}=0.81\right)$. 
There was no relationship observed between concentration and discharge.

Figure 5 shows the state of the watershed for each high-flow event studied. Some points shown correspond to high flows whose watershed state was not observed (at the beginning of the study period; see table I). These data were not taken into account when calculating the correlations, but their locations in figure 5 supports the existence of four families of points corresponding to the identified watershed states.

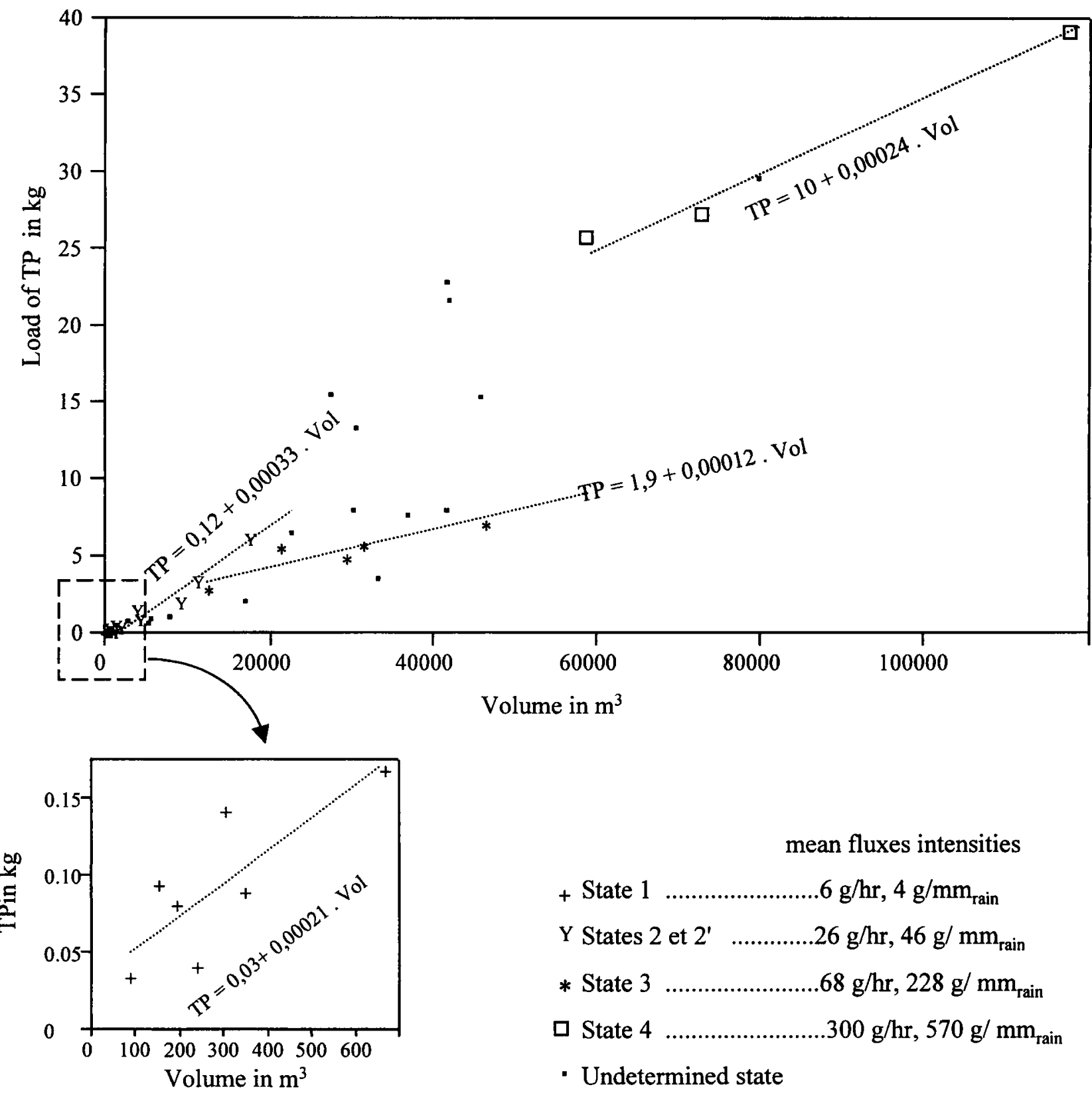

Figure 5. Relationship between water volume and TP flux and high-flow typology. 
The first family corresponds to state 1 when the high flows did not directly mobilize the agricultural phosphorus. The linear regression slope of "volume/load' (Vol-load) was $0.2 \mathrm{mg} . \mathrm{L}^{-1}\left(\mathrm{r}^{2}=0.63\right)$. The mean instantaneous phosphorus flux amounted to $6 \mathrm{gP.h}^{-1}$, or $4 \mathrm{gP} . \mathrm{mm}_{\text {rain }}{ }^{-1}$. The maximum exported mass per high flow was $0.2 \mathrm{~kg}$. No relation could be established between the exported mass and the duration of the previous low water condition of these high flows.

The second family of points contained all of the high flows corresponding to watershed state 2. TP mean concentration was higher because the slope of ratio Vol-load was $0.33 \mathrm{mg} . \mathrm{L}^{-1}\left(\mathrm{r}^{2}=0.93\right)$. The mean instantaneous flux was disproportionally higher compared to state 1 values $\left(26 \mathrm{~g} \cdot \mathrm{h}^{-1}\right.$ and $46 \mathrm{~g} \cdot \mathrm{mm}_{\text {rain }}{ }^{-1}$ ).

The high flows corresponding to state 3 shared a narrow range of volumes with the high flows of state 2 (between 10000 and $20000 \mathrm{~m}^{3}$ per high flow). The lowest mean TP concentration characterizing these high flows $\left(0.12 \mathrm{mg} \cdot \mathrm{L}^{-1}\right)\left(\mathrm{r}^{2}=0.85\right.$ for the relationship between volume and TP load), could be explained by the diluting effect of low TP water from the forested zone and the flat zones (figure 4a). Phosphorus fluxes increased to 68 gP. $\mathrm{h}^{-1}$ and $228 \mathrm{gP.mm}{ }_{\text {rain }}{ }^{-1}$. No data on this type of high flow were recorded for water volumes of more than $50000 \mathrm{~m}^{3}$.

With a further increase in the volume of stream flow, a new threshold was crossed resulting in state 4 high flows. This increase in volume was accompanied by the highest instantaneous flows observed (> $1000 \mathrm{~L} . \mathrm{s}^{-1}$ ) and brought about fluxes of 300 $\mathrm{gP} . \mathrm{h}^{-1}$. The volume/flow regression slope was similar to that of type 3 , but was displaced to a higher position by an intercept equivalent to $10 \mathrm{~kg}$ TP. This value could represent runoff access to new phosphorus stocks.

\subsubsection{State of the watershed and speciation of exported phosphorus}

The phosphorus species SP and PP and their relationship to TSS were analysed to provide additional insight into phosphorus transfer dynamics in the Mercube. The SP was made out of a constant fraction of orthophosphate $(70 \%)$. The fraction of SP in TP at the outlet was under $50 \%$ (figure $6 a$ ) for states 1, 2 and 3. In contrast, the soluble fraction of TP was 60 to $80 \%$ just downstream of the active zones (grab samples). This emphasizes the important role played by sediment. The mean percentage of SP in relation to TP gradually diminished from watershed state 1 to state 4 . The variability of this ratio also tended to decrease. Figure $6 b$ shows an overall decrease in TSS phosphorus content with volume, i.e. from one state to another. The variability in each state could also be explained by variations in volume. State 4 highflows systematically showed low values $\left(<800 \mu \mathrm{gP}^{-\mathrm{g}^{-1}}\right.$ of P in TSS). This lower P concentration could either be the result of increased transport capacity (coarser particules moved, having the least specific exchange surface) or represent access to different phosphorus reserves during strong high flows, notably the erosion of banks having low phosphorus concentrations. As states 1,2 and 3 showed no signs of erosion on the fields, they could preferentially transfer sediments from the main and secondary branches of the hydrologic network.

Variations in speciation are therefore consistent with the identified typology of watershed states. Hence the state of a watershed during high flow leads to a specific flow and speciation (table $I V$ ).

\section{DISCUSSION AND CONCLUSION}

The Mercube study area is characterized by variable and diverse sources of diffuse phosphorus pollution that are related to the diversity of soil uses in the watershed. The annual areal export of TP $\left(0.5 \mathrm{~kg} \mathrm{ha}^{-1}\right.$.year-1 of which $70 \%$ PP) is in the lower range of values found in the literature for equivalent land uses $[58,65] .93 \%$ of total annual phosphorus load is exported during high flow, of which $80 \%$ in the form of PP and $13 \%$ as SRP. The mean concentrations of these exports at the outlet $\left(0.12 \mathrm{mg} . \mathrm{L}^{-1} \mathrm{PP}\right.$ and $\left.0.03 \mathrm{mg} . \mathrm{L}^{-1} \mathrm{SP}\right)$ exceeds the recommanded levels set by CIPEL 


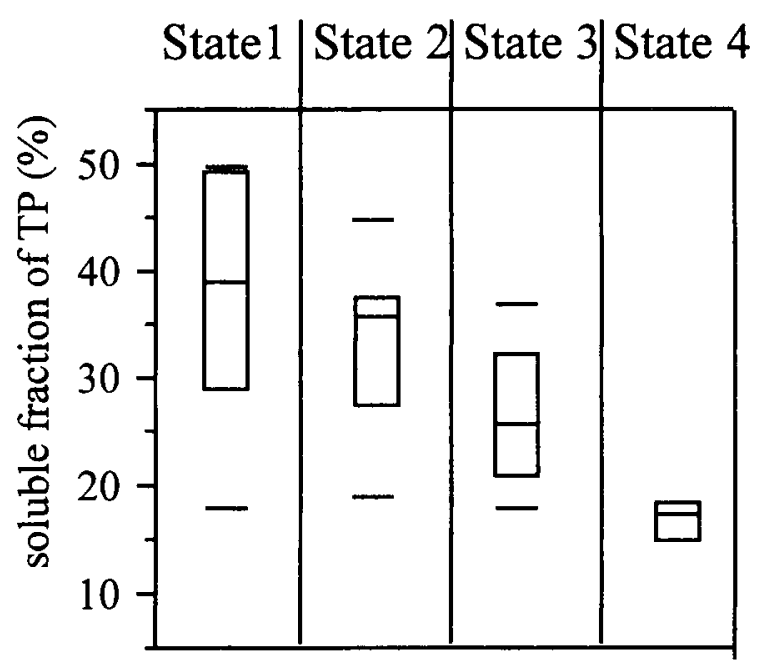

b)

\begin{tabular}{|rl|}
\hline+ & State 1 \\
$\mathrm{Y}$ & States 2 et 2' \\
$*$ & State 3 \\
$\square$ & State 4 \\
\hline
\end{tabular}

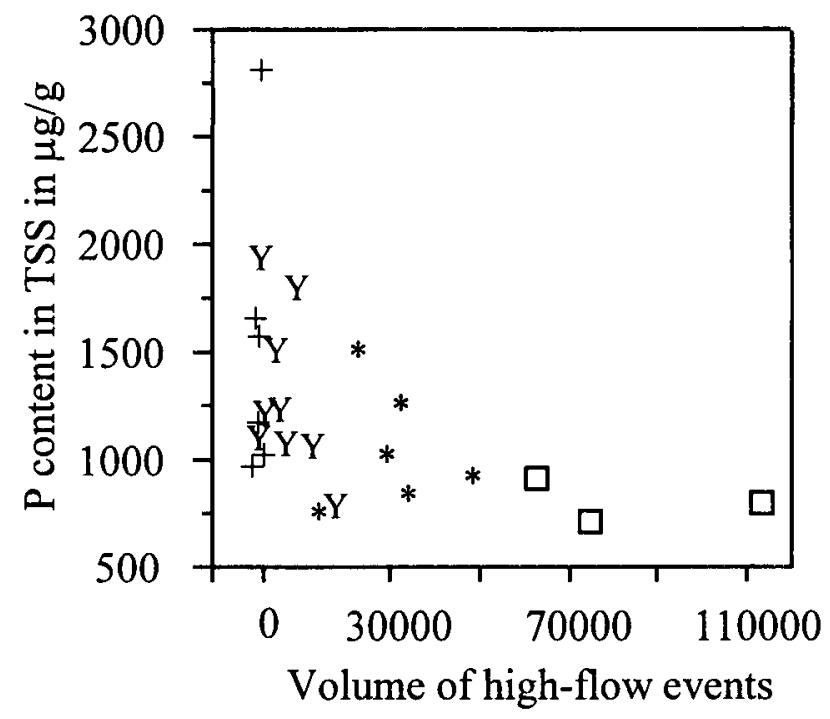

a)

Figure 6a. Influence of the state of the watershed on speciation of exported phosphorus. Percentage of SP. b. Influence of the state of the watershed on speciation of exported phosphorus. Relationship between water volume and $P$ content of TSS.

Table IV. Recapitulation of the different parameters in relation to the potential impact of the four types of high flow.

\begin{tabular}{|c|c|c|c|c|c|c|c|c|}
\hline Sate 1 & 6 & 41 & 396 & 137 & 1565 & maximum & 13 & 1 \\
\hline State 4 & 300 & 17 & 378 & 64 & 736 & $\mathrm{f}$ (season) & 13 & 46 \\
\hline
\end{tabular}


exceeds the recommanded levels set by CIPEL [14] for Lake Léman.

\subsection{Variability and dynamics of phosphorus exports}

By monitoring the TP exports at the outlet over a 4-year period, we have been able to document a high flux variability, ranging from 1 - to 3 -fold for TP from year to year, and 1- to 100-fold from one high flow to another. This high amplitude is linked to the complex sources and mechanisms of transfer of TP in both the stream and the diverse landscape of the watershed. In the studied watershed, mechanisms of runoff generation and phosphorus mobilization and transfer varied from one high flow to the next, and from one cultivated field to another.

First, TP loss can be due to runoff from saturated soils at the bottom of slopes. Under these conditions, runoff water contained a high proportion of soluble phosphorus. Three hypotheses could explain this particular form of phosphorus emission:

- the mobilization of SP stocks is carried out by surface runoff itself (extraction of water and SP contained in the upper centimeters of the soil [69]).

- SP release is caused by the very low Eh level in waterlogged soils [40].

- SP is mobilized on slopes during infiltration, then transferred into the subsurface by lateral transfer along an impermeable horizon or above the tillage pan [23]. For a high concentration of SP to be maintained down to the base of sloped fields, either transfer must occur rapidly through specialized pathways, or soil phosphorus concentration must be high and close to saturation in order to favor ion phosphate mobility [28, 29, 32, 71].

This type of non-erosive runoff precedes widespread erosion of soil resulting in runoff with high PP concentrations. Other experimental [17] and field studies $[2,50]$ have described a similar temporal sequence of runoff and erosion under equivalent field conditions. Thus, in general, SP fluxes are not directly coupled to the PP fluxes because stocks, active periods, and mechanisms of transfer are often different.

Finally, noticeable phosphorus transfer was also associated with artificial drainage and flooding in flat areas. According to Oygarden et al. [59], high concentrations in underground drainage water can arise owing to preferential transfert of colloidalsize particles through soil cracks and macropores. It can also occur by means of low Eh conditions [40]. According to Smith et al. [73], the SRP concentration of underground drainage water is proportional to phosphorus soil enrichment with a net increase when the $\mathrm{P}_{\text {Olsen }}$ content in the soil exceeds

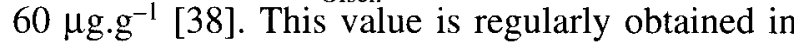
our cultivated soils $[32,71]$ and is well over the optimum cultural yield response [54]. Therefore, soil over-fertilization seems to aggravate the transfer of soluble forms of phosphorus through the upper soil horizons. Extensive leaching has already been observed in sandy fertilized soils (5 $\mathrm{kg} \cdot \mathrm{ha}^{-1} \cdot$ year $\left.^{-1},[78]\right)$ and organic soils (18 $\mathrm{kg} \cdot \mathrm{ha}^{-1} \cdot \mathrm{year}^{-1}$, [53]). As a consequence, unlike as was believed in the past, phosphorus flux is not wholly independent of the quantity of phosphorus in soil stocks.

\subsection{States of watershed and high-flow events typlology}

Seasonal changes in runoff characteristics, in connections to the hydrologic network, and in intensity of precipitation, control the flux of phosphorus at the outlet. This concept was used as the main basis for our typology of the watershed states linking hydrological functioning and phosphorus stocks to the quantity and speciation of phosphorus exported at the outlet.

State 1 concerns summer high flows, which only affect the stocks deposited on urban impervious surfaces and the sediments from within the currently active hydrologic network. The mass of exported phosphorus for each high flow is low (the maximum observed export corresponded to a flux of 0.1 $\mathrm{kg}$ per ha of impervious surface). The amount of phosphorus exported during this type of high flow 
only represented $1 \%$ of that exported during all the high-flow events (table IV). However, exports take place when the surface water's (Lake Léman in our case) sensitivity to nutrient input is at a maximum, mainly because of high temperatures and light intensity. In addition, the phosphorus forms exported (hight [SP] and PP/TSS) were very favorable to algal growth. Indeed, soluble fraction is considered to be totally available [68]. Potential bioavailability of particulate phosphorus is more variable [74] but often proportional to the suspended matter phosphorus content [25].

The active zone for state 2 high flows expands to include new phosphorus stocks mainly linked to runoff from the saturated bases of slopes. Under these conditions, the phosphorus originates from agricultural land with high soluble SP concentrations (up to $0.35 \mathrm{mg} . \mathrm{L}^{-1}$ ) and from the sediments from the expanded hydrologic network. The network was fully extended during the transition from state 2 to state 3 , but the newly connected zones (essentially just the forested zones) resulted both in flow increase and concentration decrease. The SP content of type 3 high flows is also higher than the values usually rapported in the literature $[39,44$, 67]. High flows of types 2 and 3 constituted three quarters of the high-flow events and the magnitude of these events was 4- to 10 -fold that of state 1 events (table IV). State 2 high-flow events had a greater potential impact than those of state 3 owing to the potential bioavailability of the forms of phosphorus transferred and the susceptibility of the receiving waters to $\mathrm{P}$-induced enhanced algal growth. During states 2 and 3, the contribution of the stored phosphorus in the hydrologic network is needed to explain the observed concentrations in PP at the outlet. The opposite tendency was observed for SP which was more concentrated at the field-scale than at the outlet. This could be due to the existence of partial insolubilization phenomena during transport. The studies of Svendsen et al. [76] and Dijkhuis et al. [19], in other areas, confirms that soluble phosphorus can be preferentially emitted from agricultural zones, while particulate phosphorus mostly originates from the hydrologic network. Finally, for the high-flow events corresponding to states 1,2 and 3, which represent the very large majority of high-flow events, the CREAMS [29] is not applicable because of the absence of erosion and the high percentage of soluble phosphorus forms in the surface water network. Actually, SP emission is not often cited as a major mechanism for phosphorus export during highflow events or as a major component of TP export on an annual basis.

Erosion in the active zones, occurring with extreme meteorological events or combinations of unfavorable agro-meteorological factors provoked the high-flow state (state 4, two or three times a year). This state was characterized by a high concentration of PP either downstream of the fields or at the outlet (up to $1.5 \mathrm{mg} . \mathrm{L}^{-1}$ ). Despite the infrequent occurrence, about half of the annually exported phosphorus moved during these events (table IV). Diffuse phosphorus pollution models emphasize this type of phosphorus emission. Several factors may diminish the impact of these high quantities of TP on receiving lake waters. First, this state 4 phosphorus flux is potentially the least bioavailable (low TSS phosphorus content and low SP concentration). Second, only a few of these state 4 high flows occur during periods of high lake susceptibility to P-enhanced algal growth and the transfer is accompanied by large quantities of suspended matter, which can reduce algal growth in the lake [74].

\subsection{Conceptual model of phosphorus transfer}

This spatio-temporal analysis of diffuse phosphorus pollution has led us to propose a phosphorus transfer concept that decouples soluble and particulate phosphorus transfer mechanisms. PP transfer is a non-continuous phenomenon usually requiring a specific sequence of prior conditions (stages 1-3). Many of the high-flow events only release the non-consolidated sediment stocks of the hydrologic network without replenishing the stocks. The highest-flow events causing massive PP transfer can refill this stock from soil and stream banks. Thus the amount of PP exported at the outlet during each high-flow event is often not 
directly determined by soil processes (runoff, erosion). In contrast, SP depends on the soluble and colloidal stocks present in the soil surface horizons $[28,29]$. Thus, in general, SP fluxes are not directly coupled to the PP fluxes because stocks, active periods, and mechanisms of transfer are often different. The mobilization of SP stocks is carried out either by surface runoff, or by subsurface transfer. These phenomena are dominant in all the cases where runoff is not erosive. During transfer, phosphorus exchange between water, suspended matter and sediment can modify phosphorus speciation, controlled by the amount of time these components interact. Thus, watershed size and network arrangement can have an important effect on the phosphorus forms and amounts reaching the stream outlet.

\subsection{Phosphorus management}

The relative independence between SP and PP, the dominance of hydrological factors, the variability of transfer modes, and the important role of exceptional events are all important in finding an answer to how diffuse phosphorus pollution can be controlled. The control of TP export as if it was only an erosive process is not sufficient (minimizing tillage [75]; maintaining maximal cover, notably by mulching [43]; intercepting erosion from fields with vegetated buffer strips [87]). This approach is too restrictive both because it targets specific crops and leads to only a few best management pratices. The choice of the usual target crops is mainly based on an evaluation of their annual areal loads taken in the literature [63]. This does not take into account either the individual variation in cultivation practices or the variability of hydrological phenomena that affect phosphorus transfer. In addition, the erosion control strategy does not take soluble phosphorus into account. The few studies evaluating this control approach in areas of gentle relief found little change in TP exported due to the increase in soluble phosphorus (SP) transfer $[43,75]$. Over the course of many years, as TP stocks in the soil increase, we should expect the proportion of SP in emission to increase, thus mak- ing this approach to reducing TP export even more inefficient [12]. Similarly, despite short-term promising results using vegetated buffer strips to reduce phosphorus export, the long-term increase in phosphorus stocks in the landscape will not be alleviated by this approach [20].

The management of phosphorus export needs a series of actions from the field- to the watershedscale [23]. At the field-scale, control inevitably involves reducing the surplus stocks in the soil by reducing phosphorus inputs. This is the only longterm approach to reducing SP fluxes transferred via surface flow or through subsurface pathways. But there is still no agreement on the threshold concentration of phosphorus in the soil where these transfers commence [32]. At the scale of groups of fields, TP export reductions may be achieved through another arrangement of fields. Little attention has been given to this approach, but careful analysis of inputs and outputs from different field types could result in a reduction in exports to surface water drainages. At the watershed-scale, optimal use or even restoration of the existing buffer zones needs to be implemented in marshland and riparian areas [47], flood plains [16] and wet grassland [52]. Some results obtained at the landcape level suggest that the watershed size and network arrangement can have an important effect on the phosphorus forms and amounts reaching the stream outlet $[8,84]$. All these existing data need to be completed by knowledge on social and economic feasibility to obtain a generalized plan of action to be suggested.

\section{REFERENCES}

[1] Alström K., Bergmann A., Sediment and nutrient losses by water erosion from arable land in South Sweden. A problem with nonpoint source pollution, Vatten 44 (1988) 193-204.

[2] Angéliaume A., Ruissellement, érosion et qualité des eaux en terre de grande culture. Étude comparée de deux bassins versants du Laonnois et du Soissonnais, thèse de doctorat, université de Lille, 1996, 488 p. 
[3] Arvieu J.C., Bouvier O., Les processus chimiques de l'évolution des phosphates en sols calcaires, Science du sol 4 (1974) 207-224.

[4] Balvay G., Évolution du zooplancton du Léman, Rapport Comm. int. prot. eaux Léman, Campagne 1995, Lausanne, 1996, 117-132.

[5] Barroin G., La pollution par les phosphates, Ademart, 1991, 15 p.

[6] Blanc P., Corvi C., Nirel P., Revaclier R., Rapin F., Évolution physicochimique des eaux du Léman, Rapp. Comm. int. prot. eaux Léman, Campagne 1995, 1996, 37-80.

[7] Boiffin J., Papy F., Eimberck M., Influence des systèmes de culture sur les risques d'érosion par ruissellement concentré. Analyse des conditions de déclanchement de l'érosion, Agronomie 8 (1988) 663-673.

[8] Braun D.C., Windhausen L.J., Wang D., Patterns of phosphorus export in relation to land use in the Laplatte River Basin, Vermont, School of Natural Resources, Burlington, Int. Report, 1996, 50 p.

[9] Brochet P., Gerbier N., L'évapotranspiration. Aspects agronomiques, évaluation pratique de l'évapotranspiration potentielle, Monographies de la météorologie nationale (1968) 65, 25-28.

[10] Burrus D., Contribution à l'étude du transport du phosphore dans le Rhône alpin, thèse, université de Genève, Institut Forel, 1984, 100 p.

[11] Casey H., Farr I.S., The influence of withinstream disturbance on dissolved nutrient levels during spates, Hydrobiologia 92 (1982) 447-462.

[12] Cassell E.A., Dorioz J.M., Kort R.L., Hoffmann J.P., Meals D.W., Kirschtel D., Braun D.C., Watershed modeling: dynamics of phosphorus storage, cycling, transport and export, J. Environ. Qual. (1998) in press.

[13] Cipel, Le Léman. Synthèse de 1957 à 1982, Commission internationale pour la protection des eaux du Léman, Lausanne, 1984, 647 p.

[14] Cipel, Rapport de l'étude des pollutions diffuses dans le bassin lémanique, Commission internationale pour la protection des eaux du Léman, Lausanne, 1988. $128 \mathrm{p}$.

[15] Cipel, Rapports sur les études et recherches entreprises dans le bassin lémanique, campagne 1987, Commission internationale pour la protection des eaux du Léman, Lausanne, 1988, 268 p.

[16] Conrad A.R., Falkum ф., Hansen C.D., Kronvang B., Svendsen L.M., Retention of particulate nutrients within aquatic macrophyte patches on the floodplain, Proc. Int. Workshop, Silkeborg, Denmark, NERI Technical Report, 1996, 130-134.

[17] Cros-Cayot S., Distribution spatiale des transferts de surface à l'échelle du versant. Contexte armoricain, thèse, ENSA, Rennes, 1996, 218 p.

[18] Diaz O.A., Reddy K.R., Moore P.A., Solubility of inorganic phosphorus in stream water as influenced by $\mathrm{pH}$ and calcium concentration, Wat. Res. 28 (8) (1994) 1755-1763.

[19] Dijkhuis A.H., Hoekstra N.K., Lijklema L., Van der Zee S., Origin of peak concentrations of phosphate during high discharges in a rural watershed, Hydrobiologia 235/236 (1992) 257-260.

[20] Dillaha T.A, Sherrard J.H., Lee D., Shanholtz V.O., Mostaghimi S., Magette W.L., Use of vegetative filter strips to minimize sediment and phosphorus losses from feedlots. Phase I: Experimental plot studies, VWRRC Res. Bull. 151 (1986) 21 p.

[21] Dorioz J.M., Pilleboue E., Ferhi A., Dynamique du phosphore dans les bassins versants : importance des phénomènes de rétention dans les sédiments, Wat. Res. 23 (1989) 147-158.

[22] Dorioz J.M., Fate of sediment and nutrient in watersheds. Sediment and Phosphorus, Int. Workshop, Silkeborg, Denmark, Report on session IV, 1996, 14-15.

[23] Dorioz J.M., Ferhi A., Pollution diffuse et gestion du milieu agricole: transferts comparés de phosphore et d'azote dans un petit bässin versant agricole, Wat. Res. 28 (2) (1994) 395-410.

[24] Dorioz J.M., Trevisan D., Vansteeland J.Y., Transferts diffus de phosphore des bassins versants agricoles vers les lacs: impacts, ordre de grandeur, mécanismes, in: L'eau et les agrosystèmes, t. I, Inra, Paris, 1997.

[25] Dorioz J.M., Pelletier J., Benoit P., Propriétés physicochimiques et biodisponibilité potentielle du phosphore particulaire selon l'origine des sédiments dans un bassin versant du Léman (France), Wat. Res. 32 (2) (1998) 275-286.

[26] European Norm ISO 10304-1, Dosage des ions fluorure, chlorure, nitrite, orthophosphate, bromure, nitrate et sulfate dissous, par chromatographie des ions en phase liquide. 1. Méthode applicable pour les eaux faiblement contaminées. Qualité de l'eau, Afnor, t. 3, 1995, 372 p.

[27] European Norm EN 1189, Le dosage du phosphore. Qualité de l'eau, Afnor, t. 3, 1996, 372 p. 
[28] Flanagan D.C., Foster G.R., Storm pattern effect on nitrogen and phosphorus losses in surface runoff, Trans. ASAE 32 (1989) 535-544.

[29] Frere M.H., Ross J.D., Lane L.J., The nutrient submodel, in: Knisel W.G. (Ed.), CREAMS, a field scale model for chemical, runoff and erosion from agricultural management systems, Conservation Research Report $n^{\circ} 26$, US Department of Agriculture, Washington, DC, USA, 1980, 65-87.

[30] Frere M.H., Woolhiser D.A., Caro J.H., Stewart B.A., Wischmeier W.H., Control of non point water pollution from agriculture: some concepts, J. Soil Wat. Conserv. 32 (6) (1977) 205-212.

[31] Gafrej R., Modélisation conceptuelle du transfert des matières en suspension ; effets d'échelles spatiotemporelles, thèse, université Paris-VI, 1993, 184 p.

[32] Giroux M., Carrier D., Beaudet P., Problématique et méthode de gestion des charges de phosphore appliquées aux sols agricoles en provenance des engrais de ferme, Agrosol. 9 (1996) 36-45.

[33] Golterman H.L., Theorical aspects of the adsorption of ortho-phosphate onto ironhydroxide, Hydrobiologia 315 (1995) 59-68.

[34] Grant R., Laubel A., Krongvang B., Transport of sediemnt and phosphorus in the arable Gelbaek catchment, Denmark. Drainage water, in: Proc. Int. Workshop, Silkeborg, Denmark, 9-12 October 1995, Technical Report, 1995, 71-74.

[35] Haddrill M.V., Keffer R., Olivetti G.C., Polleri G.B., Giovanardi F., Eutrophication in Emilia Romagna, Italy. Monitoring the nutrient load discharged to the littoral zone of the adriatic sea, Wat. Res. 5 (1983) 483-495.

[36] Hamid S., Dray M., Ferhi A., Dorioz J.M., Traçage isotopique des mouvements de l'eau en terrain fluvioglaciaire : étude intégrée à l'échelle d'une parcelle d'un sous bassin et d'un bassin versant. Isotopes techniques, in: Water Resource Development, Symposium IAEA, Vienne, 1987.

[37] Haygarth P.M., Jarvis S.C., Soil derived phosphorus in surface runoff from grazed grassland lysimeters, Wat. Res. 31 (1997) 140-148.

[38] Heckrath G., Brokkes P.C., Poulton P.R., Goulding K.W.T., Phosphorus loading from soils containing différent phosphorus concentrations in the Broadbalk Experiment, J. Environ. Qual. 24 (1995) 904-910.

[39] Johnson A.H., Bouldin D.R., Goyette E.A., Hedges A.H., Phosphorus loss by stream transport from a rural watershed: quantities, processes and sources, J. Environ. Qual. 5 (1976) 2, 148-157.

[40] Jordan T., Correll D., Weller D., Nutrient interception by a riparian forest receiving inputs from adjacent cropland, J. Environ. Qual. 22 (1993) 467-473.

[41] Jordan-Meille L., Dorioz J.M., Mathieu N., Approche expérimentale par crue artificielle de la participation du réseau hydrographique à l'exportation de $\mathrm{P}$ dans un petit bassin agricole, Wat. Resour. Res. (1998) in press.

[42] Kauark Leite L.A., Réflexions sur l'utilité des modèles mathématiques dans la gestion de la pollution diffuse d'origine agricole, thèse, École nationale des ponts et chaussées, Paris et Cergrene, Noisy le Grand, $1990,342 \mathrm{p}$.

[43] Koro N., Bernard C., Laverdière M.R., Contrôle du ruissellement, de l'érosion et des pertes de phosphore par les résidus de culture sous pluie simulée, Étude et gestion des sols 2 (3) (1995) 173-182.

[44] Kronvang B., Sediment-associated phosphorus transport from two intensively farmed catchment areas, Soil Erosion Agric. Land (1990) 313-330.

[45] Laflen J.M., Lane L.J., Foster G.R., WEPP: A new generation of erosion prediction technology, J. Soil Wat. Conserv. 46 (1991) 34-38.

[46] Le Bissonnais Y., Papy F., Les effets du ruissellement et de l'érosion sur la turbidité de l'eau, Inra et l'eau, Inra, Paris, 1997.

[47] Lee G.F., Bentley E., Amundson R., Effect of marshes on water quality, in: Coupling of Land and Water Systems, Ecological Studies 10, Springer-Verlag, New York, 1975, 105-127.

[48] Likens G.E., Borman F.H., Pierce R.S., Eaton J.S., Johnson N.M., Biochemistry of a forested ecosystem, Springer-Verlag, New York, 1977, $146 \mathrm{p}$.

[49] Lowrance R., Effects of buffer systems on the movment of $\mathrm{N}$ and $\mathrm{P}$ from agriculture to streams, in: Holder V. (Ed.), Int. Conf. on N, P and Organic Matter, Luna Tryk ApS, Copenhagen, 1991, 87-96.

[50] Ludwig B., Auzet A.V., Boiffin J., Papy F., King D., Chadœuf J., États de surface, structure hydrographique et érosion en rigole de bassins versants cultivés du Nord de la France, Étude et gestion des sols 3 (1) (1996) 53-70.

[51] Meybeck M., Carbon, nitrogen and phosphorus transport by world rivers, Am. J. Sci. 282 (1982) 401-405.

[52] Mérot $P$., Inventaire des processus de transfert sur un bassin versant. Rôle de l'organisation des sols, 
in: Les flux dans les volumes pédologiques et à leur limite: approches à l'échelle spatiale du bassin versant, Inra, Dijon, 1991, 1-16.

[53] Miller M.H., Contribution of nitrogen and phosphorus to subsurface drainage water from intensively cropped mineral and organic soils in Ontario, $J$. Environ. Qual. 8 (1979) 42-47.

[54] Morel C., Plenchette C., Fardeau J.C., La fertilisation phosphatée raisonnée de la culture du blé, Agronomie 12 (1992) 565-579.

[55] Newbold J.D., Elwood J.W., O'Neil R.V., Sheldon A.L., Phosphorus dynamics in a woodland stream ecosystem: a study of nutrient spiralling, Ecology 64 (1983) 1249-1265.

[56] Novotny V., Chesters G., Handbook of nonpoint pollution: sources and management, Van Nostrand Reinhold Environmental Engineering Series, New York, $1981,558 \mathrm{p}$.

[57] Olsen S.R., Cole C.V., Watabane F.S., Dean L.A., Estimation of available phosphorus in soil by extraction with sodium bicarbonate, Circular $\mathrm{n}^{\circ} 939$, USDA, Washington, 1954, $19 \mathrm{p}$.

[58] Ostry R.C., Relationship of water quality and pollutant loads to land uses in adjoining watersheds, Wat. Res. Bull. 18 (1982) 99-104.

[59] Oygarden L., Kvaerner J., Jenssen P.D., Soil erosion with preferential flow to drainage system in clay soils, in: Proc. Int. Workshop on sediments and phosphorus: Erosion and delivery, transport and fate of sediments and sediment-associated nutrients in watersheds, Silkeborg, Denmark, 1996, 59-62.

[60] Pelletier J., Évolution de la production phytoplanctonique dans le Léman, Rapp. Comm. int. prot. eaux Léman, Campagne 1995, 1996, 107-115.

[61] Persson G., Utilization of phosphorus in suspended particulate matter as tested by algal bioassays, Verh. Internat. Verein. Limnol. 24 (1990) 242-246.

[62] Pilleboue E., Origines, bilans et mécanismes de transfert du phosphore et de l'azote d'un bassin versant vers un lac, thèse, Paris-VI, 1987, 251 p.

[63] Rast W., Lee G.F., Nutrient loading estimates for lakes, Am. Soc. Civil Engr., Env. Engr. Div. 109 (1983) 502-505.

[64] Robert M., Rodier C., Une approche au niveau particulaire de la spéciation du $\mathrm{P}$ dans les sols, C. R. Acad. Sci. Paris IIa 321 (1995) 769-774.

[65] Ryding S.O., Rast W., Uhlmann D., Clasen J., Somlyodo L., Le contrôle de l'eutrophisation des lacs et des réservoirs, Masson, Paris, 1994.
[66] Sebetich M.J., Kennedy V.C,. Zand S.M., Avanzino R.J., Zellweger G.W., Dynamics of added nitrate and phosphate compared in a northen California woodland stream, Wat. Res. Bull. 20 (1984) 93-101.

[67] Sharpley A.N., Daniel T.C., Edwards D.R., Phosphorus movement in the landscape, J. Prod. Agric. 6 (1993) 492-500.

[68] Sharpley A.N., Smith S.J., Prediction of bioavailable phosphorus in agricultural runoff, J. Environ. Qual. 21 (1992) 32-37.

[69] Sharpley A.N., Smith S.J., Prediction of soluble phosphorus transport in agricultural runoff, J. Environ. Qual. 18 (1989) 313-316.

[70] Sharpley A.N., The effect of storm interval on the transport of soluble phosphorus in runoff, J. Environ. Qual. 9, (4) (1980) 575-578.

[71] Sims J.T., Environmental soil testing for phosphorus, J. Prod. Agric. 6, 501-507.

[72] Skaggs R.W., Brevé M.A., Gilliam J.W., Hydrologic and water quality impacts of agricultural drainage, Crit. Rev. Environ. Sci. Technol. 24 (1994) $1-32$.

[73] Smith R.V., Lennox S.D., Jordan C., Foy R.H., McHale E., Increase in soluble phosphorus transported in drainflow from a grassland catchment in response to soil phosphorus accumulation, Soil Use Manag. 11 (1995) 204-209.

[74] Sonzoni W.C., Chapra S.C., Amstrong D.E., Logan T.J., Bioavailability of phosphorus inputs to lakes, J. Environ. Qual. 11 (1982) 555-563.

[75] Staver K.W., Magette W.L., Tillage effect on phosphorus transport from atlantic coastal plain watersheds, American Society of Agricultural Engineers, Paper $n^{\circ}$ 88-2651, St Joseph, MI, 1988.

[76] Svendsen L.M., Kronvang B., Kristensen P., Graesbol P., Dynamics of phosphorus compounds in a lowland river system: importance of retention and nonpoint sources, Hydrol. Processes 9 (1995) 119-142.

[77] Stumm W., Morgan J.J., Aquatic chemistry. An introduction emphasizing chemical equilibria in natural waters, John Wiley \& Sons, 1970, 563 p.

[78] Ulen B., Drainage-associated losses of phosphorus and other nutrients from agricultural land following a consertion over to alternativ production, in: Proc. Int. Workshop on sediments and phosphorus: Erosion and delivery, transport and fate of sediments and sedimentassociated nutrients in watersheds, Silkeborg, Denmark, 1996, 63-66. 
[79] US Environmental Protection Agency, Quality criteria for water, US Gov. Print Office, Washington, DC, USA, 1976.

[80] US Environmental Protection Agency, Clean Lakes Program Guidance Manuel, Non point sources loadings, Office of Water Regulations and Standards, Washington, DC, USA, 1980.

[81] Vansteelant J.Y., Trevisan D., Perron L., Dorioz J.M., Roybin D., Conditions d'apparition du ruissellement dans les cultures annuelles de la région lémanique. Relation avec le fonctionnement des exploitations agricoles, Agronomie 17 (1997) 65-82.

[82] Van Riemsdijk W.H., Lexmond T.M., Enfield C.G., Van Der Zee S., Phosphorus and heavy metals: accumulation and consequences, in: vd Meer H.G. et al. (Eds.), Animal Manure on Grassland and Fodder Crops, 1987.

[83] Vollenweider R.A., Kerekes J., The leaching concept as a basis for controlling eutrophication: philos- ophy and preliminary results of the OECD program on eutrophication, Progr. Wat. Technol. 12 (1980) 5-38.

[84] Weller C.M., Watzin M.C., Wang D., Role of wetlands in reducing phosphorus loading to surface water in eight watersheds in the Lake Champlain Basin, 1996.

[85] Williams J.D.H., Shear H. Thomas R.L., Availability to Scenedesmus quadricauda of different forms of $P$ in sedimentary materials from the Great Lakes, Limnol. Oceanogr. 25 (1980) 1-11.

[86] Wischmeier W.H., Smith D.D., Predicting rainfall erosion losses - a guide to conservation planning, US Department of Agriculture, Agriculture Handbook $537,1978,58 \mathrm{p}$.

[87] Young R.A., Huntrods T., Anderson P.W., Effectiveness of vegetated buffer strips in controlling pollution from feedlot runoff, J. Environ. Qual. 9 (3) (1980) 483-487. 